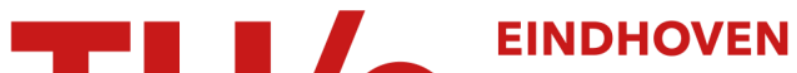 \\ UNIVERSITY OF \\ TECHNOLOGY
}

\section{Management as a profession}

Citation for published version (APA):

Romme, A. G. L. (2019). Management as a profession: a grand societal challenge. Research Features, (131). https://researchfeatures.com/2018/11/20/management-as-a-profession-a-grand-societal-challenge/

\section{Document status and date:}

Published: 01/01/2019

\section{Document Version:}

Publisher's PDF, also known as Version of Record (includes final page, issue and volume numbers)

\section{Please check the document version of this publication:}

- A submitted manuscript is the version of the article upon submission and before peer-review. There can be important differences between the submitted version and the official published version of record. People interested in the research are advised to contact the author for the final version of the publication, or visit the $\mathrm{DOI}$ to the publisher's website.

- The final author version and the galley proof are versions of the publication after peer review.

- The final published version features the final layout of the paper including the volume, issue and page numbers.

Link to publication

\section{General rights}

Copyright and moral rights for the publications made accessible in the public portal are retained by the authors and/or other copyright owners and it is a condition of accessing publications that users recognise and abide by the legal requirements associated with these rights.

- Users may download and print one copy of any publication from the public portal for the purpose of private study or research.

- You may not further distribute the material or use it for any profit-making activity or commercial gain

- You may freely distribute the URL identifying the publication in the public portal.

If the publication is distributed under the terms of Article 25fa of the Dutch Copyright Act, indicated by the "Taverne" license above, please follow below link for the End User Agreement:

www.tue.nl/taverne

Take down policy

If you believe that this document breaches copyright please contact us at:

openaccess@tue.nl

providing details and we will investigate your claim. 


\section{Management as a profession:}

A grand societal challenge

\begin{tabular}{|c|c|}
\hline $\begin{array}{l}\text { The future of management } \\
\text { as a profession is dependent } \\
\text { on the rise of new forms of } \\
\text { management, including both } \\
\text { circularity and distributed } \\
\text { leadership. This requires } \\
\text { a transition away from the } \\
\text { widespread belief that } \\
\text { management is something done } \\
\text { by a few individuals at the top } \\
\text { of an organisation. As part of } \\
\text { this transition, there is a need } \\
\text { to shift attention from human } \\
\text { agents towards management } \\
\text { technologies. Professor Georges } \\
\text { Romme, from the Eindhoven } \\
\text { University of Technology, focuses } \\
\text { his research on understanding } \\
\text { how the quest for management } \\
\text { as a science-based profession } \\
\text { can be revitalised. }\end{array}$ & 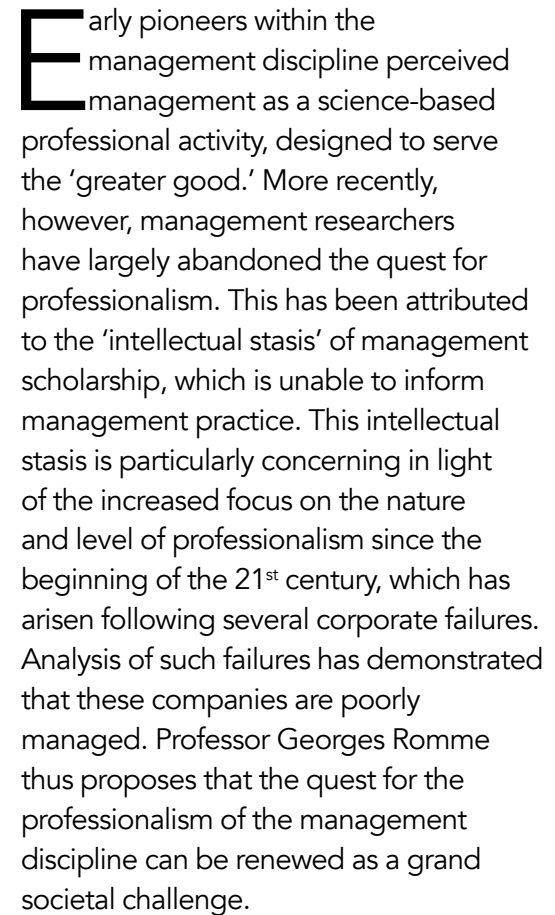 \\
\hline
\end{tabular}

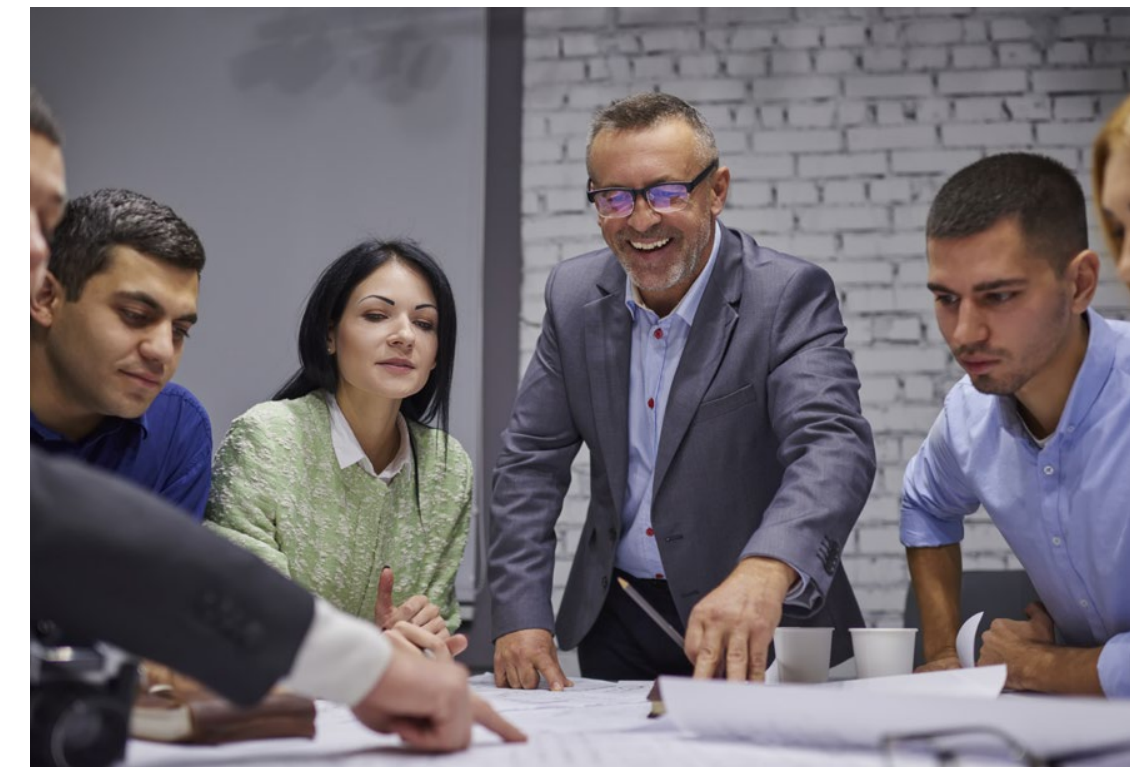

CHALLENGING ASSUMPTIONS Traditionally, it has been assumed that management is the responsibility of a few individuals at the top of an is largely unfounded Romme proposes that within professional management the evidence, tools and systems used are equally as important as the human agents within an organisation. Misconceptions about managing being carried out by a few individuals within an organisation represent a major barrier in professionalising the management discipline. This is because such a belief allows for opportunism and arbitrariness to become dominan within management practice.

In light of these issues, Romme argues that the future of the management of new forms of mant on the rise draw forms of management, which drw upon the principles of distributed allow aviation technology to be highly ftransporting people and goods. Modern aircraft contains thousands of sensors and signalling systems, whic allow the pilot to anticipate, analyse and solve problems in an automated way. However, the principles of distributed leadership are largely ignored by individuals managing other types of organisations, resulting in highly unprofessional management practices in these organisations.

\section{MANAGEMENT AND AVIATION} Drawing upon the example of aviation allows for a novel way of approaching the management discipline, according to
Romme. Management is often compared with professions such as medicine and law, the $18^{\text {th }}$ and $19^{\text {th }}$ centur. The an logy between management and aviation is thus more appropriate because both professions emerged and developed during the $20^{\text {th }}$ century.

The analogy with aviation, as well as other $20^{\text {th }}$ century professional disciplines, is also helpful because of the pragmatis understanding of the links between Aristotle's three concepts of knowledge These concepts are 'episteme', 'techne' and 'phronesis', representing scientific, instrumental and reflective knowledge respectively. These $20^{\text {th }}$ century disciplines three forms of knowledge.

In contrast to these ideas, management scholars have tended to form 'closed loops of scholarship', focusing upon nigour, relevance or reflection. the value of embracing a pragmatist, inclusive approach to effectively build a professional discipline from aviation. This would improve the ability of management scholars to guide and inform management practices. Management research as a driver of professionalisation can thus become a reality.

Despite the usefulness of the aviation and management comparison, Romme highights the limitations of this analogy. These limitations arise because the technology is more similar to the aircraf

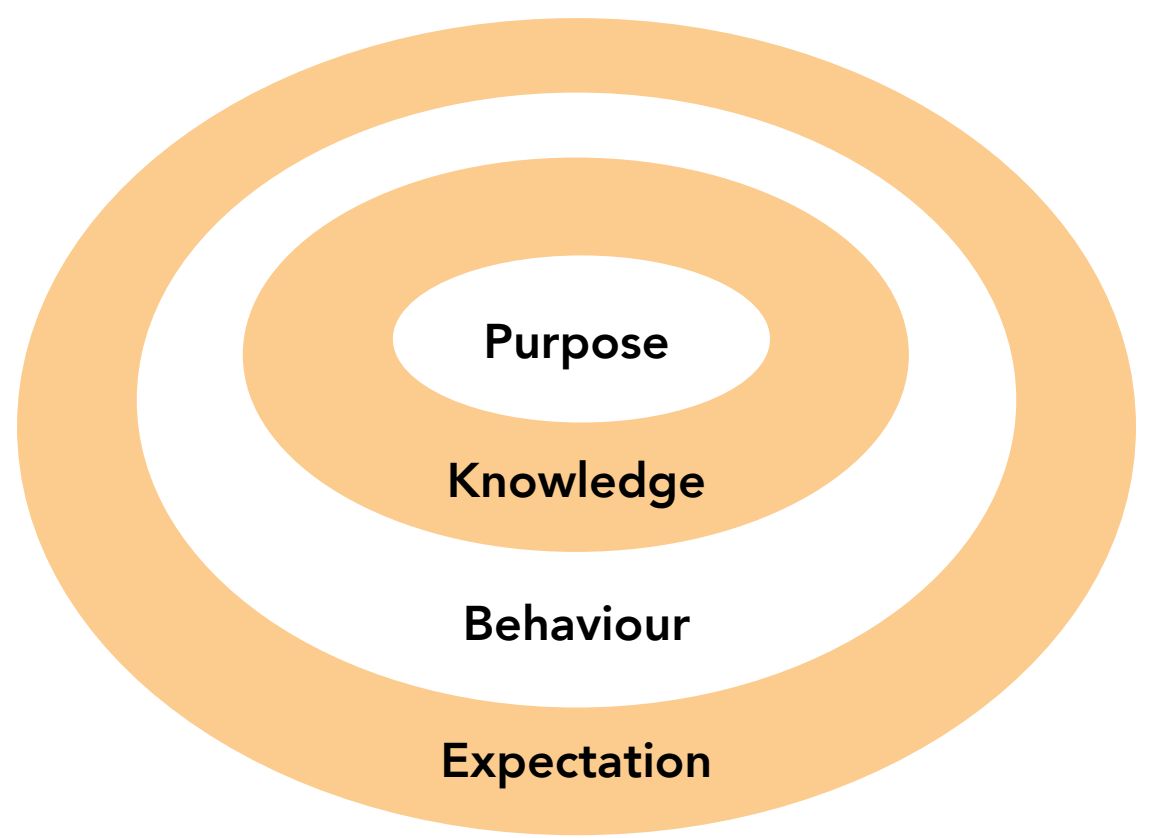

Source: Romme (2016)

can potentially act as a sensor or measuring device, which is inherently less predictable.

\section{CIRCULATION AND MANAGEMEN} in the way in which principles of distributed leadership and circularity can be applied to management. Gerard Endenburg, a Dutch engineer and entrepreneur has pioneered a 'sociocratic' approach to circular management since the 1970s. ropackaged into 'hoprach' has been circular man mo 'holact' 'These opprade

Traditionally, it has been assumed that management is the responsibility of a few individuals at the top of an organisation.

created and tested by the Wright brothers between 1903 and 1905, than modern Boeings or Airbuses. Furthermore, the wirings of aircraft are primarily intangible whereas those of management are predominantly human and social in nature. An automated pilot of an aircraft can easily monitor what is happening within the aircraft and its surroundings by using sensors and measuring devices. ha management context, however, can ease the burden of managers within an organisation, as well as driving
organisational resilience and innovation. Circular management proposes that power and leadership are distribute simultaneously maintaining a clear hierarchy. This hierarchy is conceptualised as a sequence of abstraction, rather man as levels of authent Circlar throughout an organisation, whilst take on roles as needed, rather than individuals being permanently and exclusively placed in management or other positions within an organisation. Both sociocratic and holacratic approaches are based on these principles. . all roles are defined and each individua in the In the holacratic approach, individual opportunity for each in roles, with the on multiple roles.

Several hundred organisations are currently implementing circular sociocratic or holacratic form. These tend to be small to medium-sized companies. Examples include the Dutch agribusiness Terra Viva. Large, publicly owned companies have rarely applied circular management approaches. An exception is Zappos, a division of Amazon, in which the implementation of holacracy is an ongoing effort.

Unlike sociocracy, holacracy has only been developed recently and thus it is not yet in organisations Romme highlights that in organisations. Romme highlights that companies which have implemented design agency Fabrique and the Brazilian 


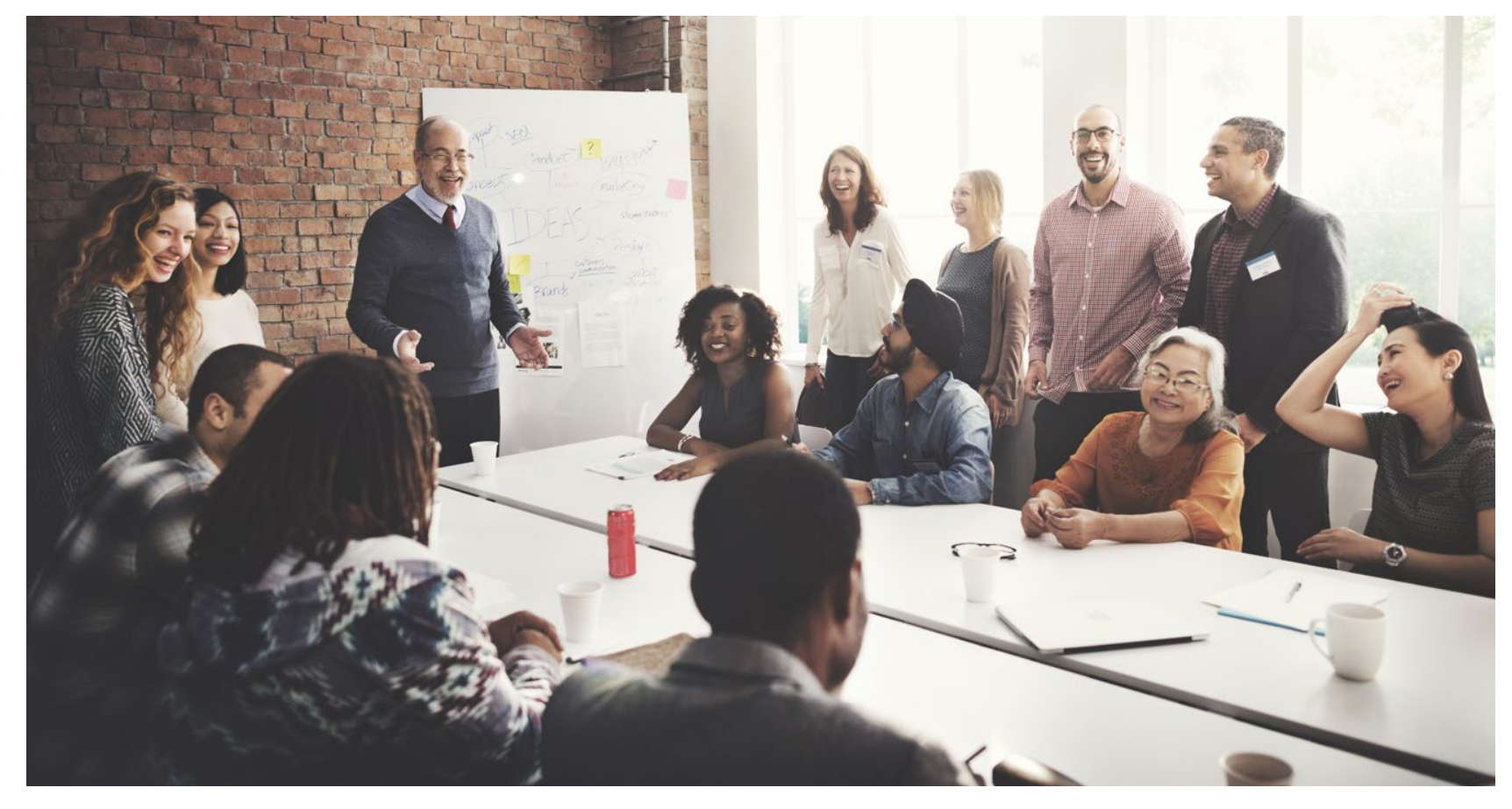

in their respective fields. Furthermore, these organisations have successfully circular power and apcles of organisational resilience and performance as well as sustain empowerment at all levels of the organisational hierarchy.

From aviation, management scholars could learn the value of embracing

a pragmatist, inclusive approach to effectively build a professional discipline.

Romme also outlines a number of misconceptions surrounding the implementation of circular management. Firstly, that implementing either sociocracy or holacracy means inevitably abandoning the corporate hierarchy. Secondly, that once the blueprint of sociocracy or holacracy has been
adopted, any strategy to achieve this

blueprint is acceptable. Thirdly, that these approaches towards management do not affect executive or supervisory boards. Romme asserts that these misconceptions can be addressed by redefining hierarchy as a sequence of abstraction, refining organisational ownership as organisations which 'own

Current versus Preferred Distribution of Professionalism (source: Romme, 2016).

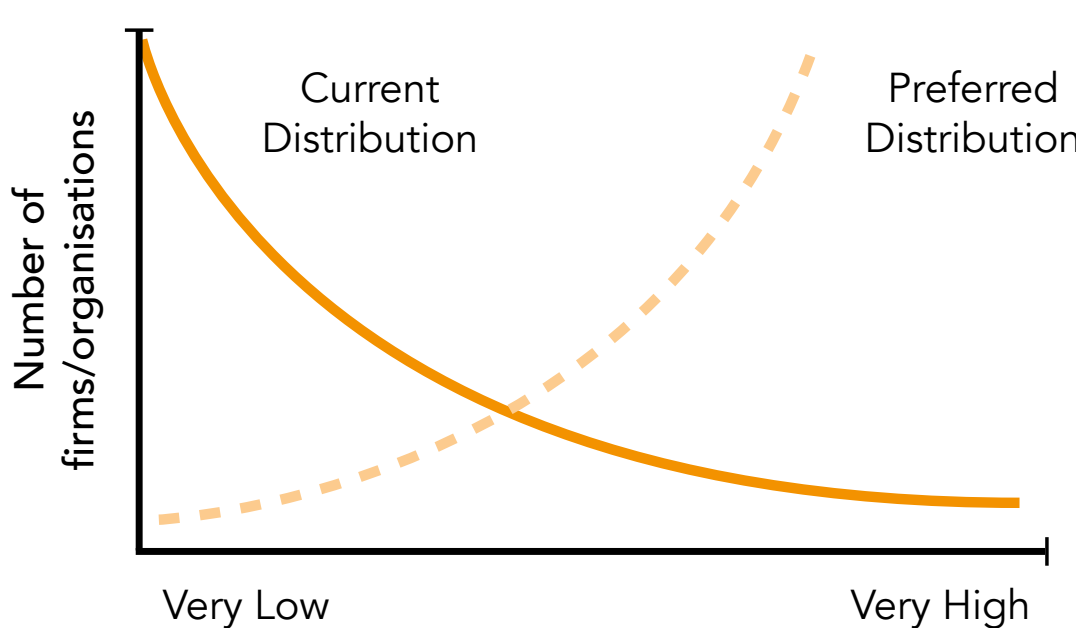

Professionalism in management consent' as the primary rule for making (i. so-called policy) decisions.

\section{MANAGEMENT PROFESSIONALIS} (INTERNAL) ATION

AS A GRAND CHALLENGE

For Romme, the quest for management as a science-based profession represents a grand societal challenge. A grand interactions and nonlinear dynamics, highly uncertain parameters and consequences as well as multiple criteria to evaluate its effectiveness. Such challenges require collective responses in which diverse individuals work together for an extended period of time. Any grand challenge has multiple solutions and thus there is a need for continuous experimentation. Circular management approaches can be conceptualised as an ongoing experiment in the quest for professionalism. Such approaches can be experimented with, along with other strategies in order to address this grand challenge.

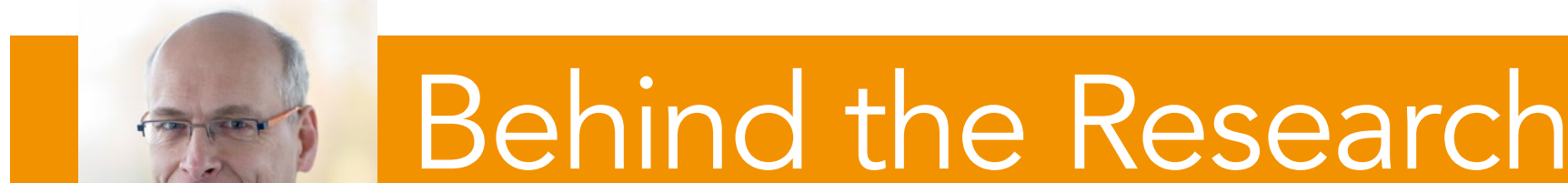

Professor Georges Romme

: a.g.l.romme@tue.nI T: $\pm 31622988319 \quad$ W: www.tue.nl/en/research/researchers/sjoerd-romme/

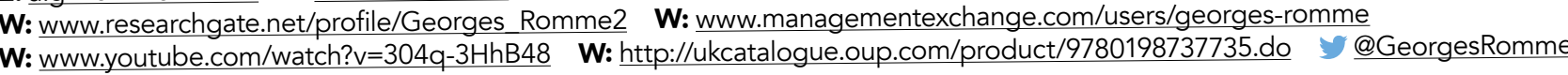

\section{Research Objectives}

Professor Georges Romme focuses his research on understanding management as a technology and how the quest for management as a science-based profession can be revitalised.

\section{Detail}

\section{Georges Romme}

Professor of Entrepreneurship \& Innovation

Eindhoven University of Technology (TU/e)

P.O. Box 513,

5600 MB Eindhoven

The Netherlands

Bio

Georges Romme is a professor of Entrepreneurship \& Innovation at Eindhoven University of Technology (TU/e). He obtained his undergraduate and graduate degrees in economics and business administration from Tilburg University and Maastricht University. From 2007 to 2014, professor Romme served as dean of Industrial Engineering \& Innovation Sciences department at TU/e, and currently is a non-executive director of several companies and nonprofits.

\section{Collaborators}

- Bob Walrave

- Jennifer van den Berg

- Pascale LeBlanc

- Gerard Endenburg

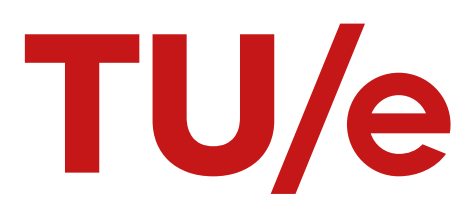

EINDHOVEN UNIVERSITY OF TECHNOLOGY

\section{References}

Romme, G. (2017). 'Management as a science-based profession: a grand societal challenge'. Managemen Research Review, 40(1), 5-9.

Romme, G. (2016). 'The quest for professionalism: The case of management and entrepreneurship'. Oxford University Press. Walrave, B., A.G.L. Romme, K.E. van Oorschot \& F. Langerak. (2017). Managerial attention to exploitation versus exploration: Toward a dynamic perspective on ambidexterity

Romme, A.G.L., M.J. Avenier, D. Denyer, G.P. Hodgkinson, K. Pandza, K. Starkey \& N. Worren. (2015). 'Towards common ground and trading zones in management research and
practice.' British Journal of Management, 26, 544-559.

Romme, G. (2015). 'The big misconceptions holding holacracy org/2015/09/the-big-misconceptions-holding-holacracy-back

Romme, A.G.L. \& G. Endenburg. (2006). 'Construction principles and design rules in the case of circular design."

\section{Personal Response}

Why do you think large companies have not
implemented circular management approaches?

III The main reason why publicly traded corporations have not adopted circular management is the fact that The constitution of these corporations still implies that shareholders appoint directors and then hold them accountable via the general meeting of shareholders. However, many by-laws in the same constitution serve to severely restrict shareholders' authority, and instead run the corporation. This separation of legal ownership and actual control of the corporation creates a highly complex distribution of power between shareholders, directors and executives: especially executives have a lot of discretion to pursue their own interests, whereas shareholders can directors when the company is underperfomple, to replace result, no one actually has the authority to decide on a transformation that will fundamentally change the position of shareholders, directors and executives. As such, a clear and unambiguous hierarchy is a key condition for making omme 